\title{
Regime político e recrutamento parlamentar: um retrato coletivo dos senadores brasileiros antes e depois da ditadura
}

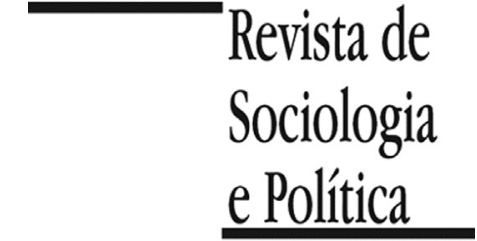

DOI 10.1590/1678-987316246005

\author{
Adriano Codato, Luiz Domingos Costa, Lucas Massimo \\ e Flavio Heinz
}

\begin{abstract}
Resumo
O artigo reconstitui os perfis coletivos das bancadas do Senado brasileiro em três períodos: a democracia populista (1945-1964), a ditadura militar (1964-1979) e o regime de transição para a democracia liberal (1979-1990). Esse intervalo de tempo compreende três sistemas partidários: multipartidário (1945-1965), bipartidário (1965-1979) e multipartidário (de 1979 em diante). A hipótese testada é a seguinte: variações no perfil social e no perfil da carreira política de parlamentares devem estar relacionadas com o tipo de regime político e, mais especificamente, com o regime de partidos em vigor. No caso aqui analisado, supõe-se que os atributos dos membros do Senado brasileiro, eleitos sob um sistema onde concorrem múltiplos partidos, deva ser diferente dos atributos dos eleitos sob o bipartidarismo, ainda que as regras eleitorais (sistema majoritário) permaneçam constantes. Para analisar o impacto das mudanças nas condições de acesso à Câmara Alta foram estudados 351 senadores. Os dados revelaram que esses representantes tiveram o perfil das suas carreiras afetado pelas variações nos parâmetros da competição política impostas pelo regime ditatorial-militar. O estrangulamento da estrutura de oportunidades, um efeito direto do sistema de dois partidos, foi responsável por alijar concorrentes sem altíssima experiência política. Com a reintrodução do pluripartidarismo nas eleições de 1982, as características das carreiras desses parlamentares retomaram o perfil anterior a 1964.
\end{abstract}

PALAVRAS-CHAVE: Senado Federal; recrutamento parlamentar; carreira política; regime político; sistema partidário.

Recebido em 14 de Janeiro de 2015. Aceito em 30 de Maio de 2015.

\section{Introdução ${ }^{1}$}

\footnotetext{
1 Agradecemos os comentários recebidos pelos pareceristas anônimos da Revista de Sociologia e Política. Este artigo resulta do estágio de pós-doutorado do primeiro autor no Departamento de Ciência Política da Universidade Paris 1 - Panthéon-Sorbonne entre 2015-2016. Bolsa CAPES (Processo n. 99999.006157/2014-09).
}

studos sobre legisladores no Brasil estão em grande medida apoiados em
informações sociográficas sobre períodos históricos recentes (Lemos
2008; Araújo 2011; Costa \& Codato 2013; Rodrigues 2014; Cervi et al.,
2015). Análises das propriedades sociais e dos itinerários políticos de depu-
tados federais e de senadores têm ignorado as transformações do recrutamento
ao longo de um intervalo de tempo mais dilatado. São raros os esforços de
verificação empírica das lógicas de seleção em legislaturas anteriores ao regime
da Constituição de 1988. Embora esse enfoque comece a mudar (Marenco dos
Santos 1997; Marenco dos Santos 2000; Santos 2000; Di Martino 2009; Neiva
\& Izumi 2014; Massimo \& Costa 2015), a ausência de fontes de acesso imediato
e de grandes bancos de dados ainda não produziu mais investigações focadas
em sequências temporais razoavelmente amplas.

Por sua vez, as pesquisas existentes sobre a classe política brasileira do passado privilegiaram investigações muito específicas (McDonough 1981; Braga 1998; Dolhnikoff 2005; Martins 2007; Codato 2015) ou análises de unidades subnacionais (Fleischer 1973; 1981; Love 1982). Estudos com corte longitudinal permanecem, contudo, marginais, seja no campo da História, seja no da Ciência Política no Brasil - uma lacuna que já foi preenchida em outros países 
${ }^{2}$ O PTB (Partido Trabalhista Brasileiro), a UDN (união Democrática Nacional) e o PSD (Partido Social Democrático) foram agremiações criadas em 1945 durante o último ano do Estado Novo brasileiro (1937-1945).

\footnotetext{
3 A ARENA (Aliança Renovadora Nacional) era o partido de apoio aos governos autoritários; o MDB (Movimento Democrático Brasileiro) era a agremiação de oposição. Apenas esses dois partidos estiveram autorizados a funcionar até 1979.

${ }^{4}$ Respectivamente: Partido Democrático Social (fundado em 1980), era o sucessor da ARENA; Partido do Movimento Democrático Brasileiro (fundado em 1980), era o sucessor do MDB; Partido Democrático Trabalhista (fundado em 1979), era o herdeiro do antigo PTB; Partido Trabalhista Brasileiro (fundado em 1980); e Partido dos Trabalhadores (fundado em 1980).
}

por projetos coletivos como o Eurelites (Best \& Cotta 2000; Best \& Edinger 2005), ou por estudos monográficos de maior fôlego, como o trabalho de Darío Cantón (1966) sobre parlamentares argentinos entre fins do século XIX e meados do século XX. Um dos resultados da ênfase da literatura sobre fenômenos recentes é que se impedem comparações do perfil da elite parlamentar em regimes políticos diferentes (onde são também diferentes as condições de competição pelas cadeiras legislativas) e um melhor entendimento da transformação diacrônica do seu retrato coletivo.

O propósito deste artigo é confrontar os atributos sociais e a estrutura de carreira dos senadores brasileiros eleitos em três períodos: 1945-1964, 1964-1979 e 1979-1990. Essas datas coincidem com o regime democrático "populista", com o regime ditatorial-militar e com o regime de transição para a democracia. Cada um desses intervalos de tempo encerrou partidos políticos e sistemas partidários diferentes. Enquanto no primeiro caso vigorou um pluripartidarismo, com a dominância de três grandes organizações (PTB, UDN e $\mathrm{PSD}^{2}$ ), extintas pela ditadura militar em 1965, a segunda temporada consagrou, até fins de 1979, o bipartidarismo da ARENA e do $\mathrm{MDB}^{3}$, e depois novamente o pluripartidarismo, mas com outras legendas e outras identidades políticas (PDS, PMDB, PDT, PTB e PT ${ }^{4}$ ). Nosso objetivo específico é determinar os modos de diversificação social e política da elite senatorial mediados por regimes de partidos diferentes entre si. A periodização que adotamos está disposta no Quadro 1.

Estudaremos os perfis dos senadores brasileiros em duas dimensões: a evolução da sua sociografia característica ao $\operatorname{logo}$ de 45 anos e as variações longitudinais de suas credenciais políticas.

A hipótese básica a ser testada no trabalho é a seguinte: as conversões morfológicas e os diferentes itinerários políticos devem estar ligados ao tipo de regime político e, mais especificamente, ao regime partidário vigente em cada fase histórica. Há, assim, uma lógica político-institucional que dirige a seleção dos competidores às cadeiras senatoriais. No caso, supõe-se que os atributos dos membros da Câmara Alta do Brasil eleitos sob um regime onde rivalizam muitos partidos devam ser diferentes - em uma medida a ser determinada empiricamente - daqueles eleitos sob o bipartidarismo, mesmo com as regras eleitorais permanecendo constantes ${ }^{5}$.

Agregamos a essa hipótese central, duas outras conjecturas secundárias a fim de testar sua validade. Elas têm a ver com o contexto político coberto pela pesquisa e com o conhecimento disponível até aqui sobre a Câmara Baixa do Brasil:

i) A ditadura militar, numa política deliberada de depuração da classe política tradicional e de recrutamento de quadros mais "técnicos", teria induzido um aumento de especialistas (engenheiros, economistas, administradores) para as posições legislativas (Nunes 1978; Santos 2000). O mesmo processo teria ocor-

Quadro 1 - Periodização dos regimes políticos e dos regimes de partidos no Brasil, 1945-1990

\begin{tabular}{ccc}
\hline fase 1 & fase 2 & fase 3 \\
\hline regime democrático-populista & regime ditatorial-militar & regime de transição \\
$\mathbf{1 9 4 5 - 1 9 6 4}$ & $\mathbf{1 9 6 4 - 1 9 7 9}$ & $\mathbf{1 9 7 9 - 1 9 9 0}$ \\
regime pluripartidário & regime bipartidário & regime pluripartidário \\
$\mathbf{1 9 4 5 - 1 9 6 5 ~}^{\text {I }}$ & $1965-1979$ & $1979-. .$. \\
\hline
\end{tabular}

${ }^{\text {I }}$ O regime pluripartidário foi interrompido com a edição do Ato Institucional n. 2 (AI-2) em 27 de outubro de 1965.

Fonte: os autores. 
${ }^{5}$ Pedersen (2000) demonstrou a transformação incremental da elite legislativa da Dinamarca em função do desenvolvimento do seu sistema partidário. rido no Executivo estadual. Alguns governadores indicados diretamente pelo Presidente da República teriam, assim, um perfil menos tradicional (Samuels \& Abrucio 2000, p.50; Santos 1971). Isso ocorreu também no Senado?

ii) Conforme os achados de Marenco dos Santos (1997) para a Câmara Baixa, teria havido uma renovação substantiva da elite entre a Constituição de 1946 e a de 1988, medida pela extensão da experiência política prévia e pela comutação na via de acesso primordial à Câmara dos Deputados, com a permuta de velhas raposas políticas por lideranças mais jovens, menos experientes e menos dependentes das máquinas partidárias tradicionais. Podemos ver isso também acontecer na elite senatorial?

O banco de dados desse experimento reúne atributos de 351 indivíduos eleitos para a Câmara Alta em 13 disputas políticas realizadas sucessivamente entre 1945 e 1990. Desses senadores, 60 se reelegeram uma vez, nove exerceram o mandato em três legislaturas, e três foram titulares em quatro mandatos, o que dá um total de 438 mandatos senatoriais. O Apêndice 1 apresenta o número de senadores eleitos para cada pleito no Brasil entre 1945 e 1990. Todos os cálculos estarão baseados no número de mandatos. Eles estão assim distribuídos (Tabela 1):

Tabela 1 - Número absoluto e percentuais de senadores eleitos no Brasil por regime político (1945-1990)

\begin{tabular}{lcc}
\hline Regime & $\mathrm{N}^{\mathrm{I}}$ & $\%$ \\
\hline democracia populista & 197 & 45,0 \\
ditadura militar & 136 & 31,1 \\
regime de transição & 105 & 24,0 \\
Total & 438 & 100,0 \\
\hline
\end{tabular}

${ }^{\mathrm{I}} \mathrm{O} N$ não é constante para cada eleição em função de alterações na legislação e da criação de novos estados (ver Apêndice 1). Além disso, o valor total desta Tabela 1 se refere ao número de mandatos, e não ao tamanho da população de senadores, que é constituída por 351 indivíduos.

Fonte: os autores.

Organizamos as informações em dois blocos: o primeiro tratou de informações básicas como ocupações profissionais prévias à atividade política, idade média de chegada ao Senado e grau e tipo de formação escolar. O segundo bloco de informações registrou a trajetória pública do senador, número e natureza dos cargos ocupados até a sua eleição ao Senado pela primeira vez e a extensão da carreira política.

O trabalho está dividido em três partes. Na primeira, fazemos um breve resumo das transformações da representação política no Brasil e da acidentada história eleitoral desse período entre 1945 e 1990. Na segunda parte, são discutidos os atributos sociais dos eleitos, seu perfil sócio-profissional, características educacionais e características etárias. Na terceira, propomos um desenho das carreiras senatoriais nos três regimes. Retomamos, ao final, a hipótese principal e as secundárias e fazemos um balanço do que foi ou não confirmado pelos dados.

\section{História política e legislativa}

O Poder Legislativo no Brasil, no nível federal, é exercício pela Câmara dos Deputados e pelo Senado Federal. Somadas, essas casas compõem o Congresso Nacional. A Câmara dos Deputados representa os eleitores. O Senado representa os estados da federação e o Distrito Federal. 
${ }^{6}$ Um exemplo dessa presença dos pequenos partidos pode ser percebida nos resultados eleitorais do PDC, em São Paulo, ou do PRP, no Rio Grande do Sul.
Senadores brasileiros são eleitos segundo o princípio majoritário em turno único. O distrito eleitoral é formado por cada unidade da federação. Cada estado e o Distrito Federal elegem, atualmente, três senadores com mandato de oito anos. Essa representação é renovada de quatro em quatro anos, alternadamente, por um e dois terços da Casa. Para ser eleito membro do Congresso Nacional no regime da Constituição de 1946 era preciso ser brasileiro (Art. 38). A Constituição de 1967 mudou a exigência e estipulou que era preciso ser brasileiro nato (Art. 30). Em ambas as Cartas a idade mínima para se candidatar ao Senado era de 35 anos. Essa regra foi mantida pela Constituição de 1988 e em 2015 foi votada uma Proposta de Emenda Constitucional para reduzir a idade mínima para 29 anos.

Entre 1945 e 1990 os senadores brasileiros foram eleitos em três regimes partidários diferentes: pluripartidário, até 1966, bipartidário até 1979 e pluripartidário novamente depois disso. Cada um desses regimes de partidos foi influenciado por parâmetros específicos de competição política, população eleitoral ativa e pelo padrão geral de liberdades de participação e oposição.

O primeiro ciclo político se iniciou ao fim da ditadura de Getúlio Vargas (1937-1945), com a aprovação da Lei Agamenon (Decreto-Lei n ${ }^{\circ} 7.586$ ) em 28 de maio de 1945. Essa Lei, que dispunha sobre a organização do alistamento, sistema eleitoral e estipulava as regras para criação de partidos políticos, proporcionou o surgimento e a nacionalização das agremiações, especialmente pela redução de 50 mil para 10 mil assinaturas em cinco ou mais circunscrições eleitorais como exigência para o registro de novos partidos. As grandes siglas deste primeiro período pluripartidário - PSD, UDN e PTB - foram criadas entre abril e julho de 1945. As três agremiações compuseram a maioria das bancadas parlamentares na Câmara e no Senado até 1966, mas também rivalizaram com pequenos partidos, muitos dos quais com representação intermitente no cenário nacional e atuação restrita a alguns estados da federação ${ }^{6}$.

Este primeiro ciclo pluripartidário é interrompido em 27 de outubro de 1965, já no contexto da ditadura militar, quando o governo de Castello Branco baixou o Ato Institucional n. 2 (AI-2), uma espécie de emenda de exceção à Constituição de 1946. Um dispositivo dessa norma, o ato complementar n. 4, determinava: "Ficam extintos os atuais Partidos Políticos e cancelados os respectivos registros". A partir das novas regras em vigor, o regime ditatorialmilitar só admitirá a partir daí dois partidos: a Aliança Renovadora Nacional (ARENA), partido que reunia as forças pró-regime, e o Movimento Democrático Brasileiro (MDB), partido que poderia se opor ao governo. Para todas as eleições majoritárias que não foram abolidas durante a ditadura militar no Brasil, incluindo a do Senado Federal, o AI-2 instituiu o mecanismo da "sublegenda": MDB e ARENA poderiam inscrever até três candidatos da mesma legenda partidária para uma mesma vaga. $\mathrm{O}$ mais votado entre os três seria o eleito.

O primeiro grande abalo no sistema bipartidário brasileiro ocorreu em 1974, quando no Senado, dos 22 eleitos, 16 eram filiados ao MDB, partido de oposição à ditadura. A partir daí, o bipartidarismo ganhou características plebiscitárias, i.e., de voto pró e contra o regime ditatorial. Para recuperar a maioria no Senado, a ditadura militar mudou as regras do jogo político. Em $1^{\circ}$ de abril de 1977 decretou um conjunto de medidas. Dentre elas, impôs a eleição indireta de $1 / 3$ de cadeiras para o Senado, dando origem ao que ficou conhecido no Brasil como "senadores biônicos" (i.e., artificiais). Estes senadores foram eleitos em 1978 por um colégio eleitoral formado por membros das Assembleias Legislativas dos estados e por delegados das Câmaras Municipais, instâncias onde a ARENA, o partido do governo, era amplamente majoritária. 
O fim do ciclo bipartidário ocorreu dois anos mais tarde, no início da transição ao regime democrático, com a aprovação, pelo Congresso Nacional, em 20 de dezembro de 1979, da Lei Federal $n^{\circ}$ 6.767, que extinguia os dois partidos criados pela ditadura e regulamentava as condições para a criação de novas agremiações. Foram criados, a partir do MDB, quatro novos partidos PMDB, PTB, PDT e PT - e a partir da ARENA uma agremiação governista unificada, o PDS. Em 1982, na nova rodada de disputa para uma cadeira no Senado, a oposição concorreu dividida.

Entre 1986 e 1990 o quadro político foi marcado por três eventos. Primeiro, a última eleição indireta para a Presidência da República sob os moldes da Constituição de 1967, em 15 de janeiro de 1985, com a escolha de Tancredo Neves (PMDB-MG) e que terminaria com a posse de seu vice, José Sarney, no mês de março daquele ano. No quadro de ampla liberalização política iniciada no período, pode-se anotar a promulgação da Emenda Constitucional 25, de 15 de maio de 1985, com a ratificação da representação de cada estado por três senadores eleitos por sufrágio universal, renovável a cada quatro anos, alternadamente, por um e dois terços, e a instituição de eleições para prefeitos de capitais. No campo social, o período conheceu um recrudescimento da mobilização de grupos sociais organizados, notadamente no meio rural, e dos embates em torno da criação do Plano Nacional de Reforma Agrária. Segundo, a convocação e realização de uma Assembléia Nacional Constituinte em 19871988. Por último, e consequência desta, a realização, em 1989, da primeira eleição direta para a Presidência da República desde aquela que elegera Jânio Quadros em 1960.

O Quadro 2, na página seguinte, resume a acidentada história políticoeleitoral entre 1945 e 1990.

Na seção seguinte apresentaremos o perfil social dos senadores brasileiros a partir da prosopografia e de maneira comparativa ${ }^{7}$. No item IV discutiremos em detalhe as características e a evolução das carreiras senatoriais nos três períodos estudados.

\section{Atributos pessoais: a lenta mudança dos padrões de seleção social da elite brasileira}

Para verificar as mudanças no perfil coletivo dos senadores brasileiros desde 1945 apresentaremos algumas informações sobre indicadores sociais básicos em estudos de elites: (i) ocupação profissional que antecede a carreira propriamente política; (ii) taxas e tipos de formação escolar; (iii) estrutura de distribuição etária dos representantes. As informações foram agrupadas por regimes políticos e regimes partidários.

\section{III.1. Os viveiros profissionais de recrutamento da elite}

\footnotetext{
7 A análise que propomos é de corte predominantemente quantitativo. Uma abordagem prosopográfica distinta, ainda que complementar sob alguns aspectos, pode ser encontrada nos trabalhos de Vargas (2010; 2012) e Hora (2014). Para uma discussão específica sobre o emprego de entrevistas em profundidade no estudo das elites políticas ver Gené (2014).
}

Desde 1932 os Códigos Eleitorais e as sucessivas Constituições brasileiras garantiram às mulheres o direito de votarem e serem votadas. Ainda assim, senadores eleitos neste intervalo de tempo são quase todos homens com duas exceções: Junia Marise (PRN-MG) e Marluce Pinto (PTB-RR) obterão suas cadeiras no Senado Federal apenas em 1990.

As ocupações profissionais de origem predominantes desse grupo não são surpreendentes (ver Tabela 2). Antes de entrarem para a política institucional, os senadores estudados foram majoritariamente empresários (em média 30\% do universo) ou atuaram em alguma profissão da área jurídica, desde advogados privados a juízes e promotores (23\% em média para os três regimes).

Não existe uma correlação inequívoca entre o tipo de ocupação de origem e o regime político/regime partidário. Seja concorrendo por muitos partidos, seja 
Quadro 2 - Principais eventos políticos e seus efeitos sobre a configuração do sistema partidário entre 1945 e 1990

\begin{tabular}{|c|c|c|}
\hline Data & Medida / Evento & Disposições \\
\hline $\begin{array}{l}28 \text { de maio de } \\
1945\end{array}$ & $\begin{array}{l}\text { Lei Agamenon, Decreto-Lei }{ }^{\circ} \\
7.586 .\end{array}$ & $\begin{array}{l}\text { Lei eleitoral que organiza o } \\
\text { alistamento e o sistema eleitoral, } \\
\text { além do registro e criação dos } \\
\text { partidos políticos. }\end{array}$ \\
\hline $\begin{array}{l}\text { Entre abril e } \\
\text { julho de } 1945\end{array}$ & $\begin{array}{l}\text { Fundação e registro dos } \\
\text { grandes partidos nacionais. }\end{array}$ & $\begin{array}{l}\text { Organização do PSD (julho), UDN } \\
\text { (abril) e PTB (maio). }\end{array}$ \\
\hline $\begin{array}{l}\text { Entre julho de } \\
1945 \text { até } 1960\end{array}$ & $\begin{array}{l}\text { Criação dos pequenos partidos } \\
\text { do período. }\end{array}$ & $\begin{array}{l}\text { Criação das siglas: }{ }^{\mathrm{I}} \text { PSB, PST, } \\
\text { PTN, PDC, MTR, PR, PRP, PPB, } \\
\text { PSP, PCB, PL e PPS. }\end{array}$ \\
\hline $\begin{array}{l}27 \text { de outubro de } \\
1965\end{array}$ & AI-2, Ato complementar $\mathrm{n}^{\circ} 4$. & $\begin{array}{l}\text { Art. 18: "Ficam extintos os atuais } \\
\text { Partidos Políticos e cancelados os } \\
\text { respectivos registros". O sistema } \\
\text { pluripartidário é transformado em } \\
\text { bipartidário. }\end{array}$ \\
\hline
\end{tabular}

15 de novembro Vitória do MDB nas eleições de 1974

1 de abril de Pacote de Abril. 1977

20 de dezembro Lei Federal $n^{\circ} 6767$. de 1979

15 de novembro Eleições diretas para de 1982 governadores dos estados.

1985 Eleição indireta para presidente da República

1990

Eleições gerais
Efeitos para o sistema partidário e para a disputa ao Senado

Proporcionou espaço para a proliferação e a nacionalização de partidos, especialmente por conta da redução de 50 mil para 10 mil assinaturas de cinco ou mais circunscrições eleitorais para o registro das novas agremiações.

Os principais partidos, com maiores bancadas no Congresso Nacional no pós-1946 e com organização nacionalizada.

Partidos menores, com representação intermitente no Senado e com organização limitada a alguns estados.

Criação dos dois partidos: Arena (pró-regime) e MDB (oposição). Instituição do mecanismo da "sublegenda": cada partido podia inscrever até três candidatos para uma mesma vaga nas eleições majoritárias (caso das eleições para o Senado). O mais votado entre os três era eleito.

Fortalecimento e nacionalização da oposição partidária ao regime ditatorial-militar. O bipartidarismo adquire características plebiscitárias.

Imposição da eleição indireta de 1/3 de cadeiras para o Senado. Aumento de 2 para 3 sublegendas.

Extinção dos partidos políticos Arena e MDB e criação de nova regulamentação dos novos partidos políticos.

Retomada da maioria governista no Senado, ampliação do número de candidatos ao Senado.

Fim do bipartidarismo e retorno ao pluripartidarismo. Fragmentação da representação partidária no Congresso Nacional. Criação do PMDB, PDS, PTB, PDT e PT.

Aumento do número de cargos para competição, maior arejamento da representação no Senado.

Emenda constitucional 25, que restabeleceu eleições para prefeito de capitais, também viabiliza resgistro de partidos de esquerda. Congresso eleito em 1986 renovará em 2/3 o Senado e comporá a Assembléia Nacional Constituinte de 1988.

Registros do PSB, PCB e PCdoB.

Declínio acentuado do PDS, partido que sucedera à ARENA. Renovação importante do Senado, apenas 4 reconduções.

${ }^{\text {I }}$ Os nomes por extenso das siglas estão listados ao final da tabela 4, na p. 58 desse artigo.

Fonte: Os autores, a partir de Souza (1976), Abreu et al. (2001) e Codato (2005). 
Tabela 2 - Ocupação prévia à carreira política dos senadores eleitos entre 1945 e 1990 no Brasil por regime político (valores percentuais)

\begin{tabular}{|c|c|c|c|c|}
\hline \multirow[t]{2}{*}{ Ocupação } & \multirow{2}{*}{$\begin{array}{c}\text { Democracia populista } \\
\text { Pluripartidarismo } \\
\end{array}$} & \multirow{2}{*}{$\frac{\text { Ditadura militar }}{\text { Bipartidarismo }}$} & \multirow{2}{*}{$\frac{\text { Regime de transição }}{\text { Pluripartidarismo }}$} & \multirow[t]{2}{*}{ Média } \\
\hline & & & & \\
\hline Empresários (rural/urbano) & 27,4 & 28,7 & 33,3 & 29,8 \\
\hline Profissões jurídicas & 27,4 & 25,7 & 15,2 & 22,8 \\
\hline Professores, militares, funcionários & 18,3 & 16,2 & 15,2 & 16,6 \\
\hline Profissionais liberais & 15,2 & 14,0 & 19,0 & 16,1 \\
\hline Políticos profissionais & 6,1 & 8,1 & 10,5 & 8,2 \\
\hline Profissionais técnicos & 5,6 & 7,4 & 6,7 & 6,5 \\
\hline Total & 100,0 & 100,0 & 100,0 & 100,0 \\
\hline
\end{tabular}

Fonte: os autores.

${ }^{8}$ Os estudos sobre elites econômicas nem sempre colocam em primeiro plano sua participação no parlamento (Costa 2014). Como exceção pode-se mencionar o trabalho de Costa, Costa e Nunes (2014), que se detém especificamente sobre os empresários que se elegeram senadores entre 1986 e 2010 . concorrendo por apenas dois, empresários do setor rural e urbano são sempre o maior contingente ${ }^{8}$. Depois de 1979, com a volta do regime de múltiplos partidos, os empresários passarão a controlar um terço das cadeiras $(33,3 \%)$. Depois de 1986 esse grupo social passa a dominar definitivamente o Senado. Em 1990 os proprietários de empresas são nada menos de 39\% da Câmara Alta. Em 2010 eles conquistaram 26\% das vagas disponíveis, voltando ao patamar do primeiro ciclo pluripartidário (Costa, Costa \& Nunes 2014; Costa \& Codato 2013).

O domínio das profissões jurídicas durante a democracia populista e durante a ditadura militar (27\% e 26\%) é digno de nota, mas nem de longe rivaliza com a hegemonia da categoria "advogados" no Senado dos Estados Unidos: entre 1943 e 1983 o percentual médio de senadores-advogados nos EUA foi de $64,6 \%$, conforme os dados calculados a partir de Miller (1995). Esse padrão, contudo, não é universal. Nos anos 1980, "Advogados eram pouco mais de cinco por cento" dos representantes nas câmaras alta e baixa do Japão, "e a maioria deles pertenciam a partidos de oposição, e não ao LDP. Essa baixa proporção de advogados diferencia os legisladores japoneses de seus colegas na maioria dos países ocidentais, especialmente dos Estados Unidos. Esse fato corresponde à baixa relação de advogados entre a população japonesa em geral" (Fukai \& Fukui 1992, p.29). Na Lituânia pós-comunista, o Parlamento era dominado por professores (em 1992, 35,5\%) e advogados contavam com apenas 2,8\% das cadeiras (Matonyte 2003, p.60). No Brasil, a categoria das profissões jurídicas diminui de maneira muito significativa, chegando no regime de transição a ser quase metade do que foi no primeiro ciclo político (caindo de $27 \%$ para apenas $15 \%$ do total).

Chamam a atenção três outras informações: (i) o número reduzido de senadores-militares durante a ditadura não inflaciona a categoria "professores, militares e funcionários" públicos, já que eles serão apenas 15 num grupo de 136 eleitos; (ii) a diminuição constante desse contingente a cada regime contrasta com o padrão observado em vários países da Europa continental e Reino Unido (Cotta \& Tavares de Almeida 2007) ${ }^{9}$; e (iii) o fato de senadores oriundos de profissões técnicas serem sempre o menor grupo em todos os regimes considerados, com uma presença em média de apenas 6,5\% da Casa.

\section{III.2. O background educacional dos parlamentares brasileiros}

${ }^{9}$ Para o mesmo intervalo de tempo considerado por nós, Cotta e Tavares de Almeida
Um estudo comparativo sobre o nível educacional dos senadores de Argentina, Brasil, Chile e Uruguai mostrou que nos primeiros anos da década de 2000 a cota dos senadores diplomados em universidades no Brasil (91\%) só não era 
descobriram que entre $30 \%$ e $40 \%$ dos parlamentares europeus vieram do setor público. Ver Cotta \& Tavares de Almeida (2007, especialmente a Figura 3.1). Os países referidos nessa pesquisa são: Dinamarca, Finlândia, França, Alemanha, Hungria, Itália, Holanda, Noruega, Reino Unido, Portugal e Espanha.
10 "Na França, os formados em Direito diminuíram a sua participação de 29\% em 1898 para $24 \%$ no período entre guerras e para $13 \%$ na Quarta República, instaurada em 1946. Na Itália, ocupavam $42 \%$ das cadeiras de deputados no início dos anos 1920 , caindo para $21 \%$ no início dos anos 1960" (Neiva \& Izumi 2012). mais alta do que a dos chilenos (96\%), mas estava bem à frente de argentinos (79\%) e uruguaios (76\%) (Llanos \& Sánchez 2006). Olhando a formação universitária dos eleitos para o Senado nos três ciclos políticos, os dados mostram que a média de graduados fica em $90,4 \%$, e a taxa mais baixa é $88,7 \%$, durante a ditadura militar.

A tendência de a elite parlamentar ser muito mais educada do que a média da população adquire, no Brasil, um contorno notável, já que a taxa de escolarização entre 1940 e 1980 sempre foi muito baixa, e a de indivíduos com curso superior, mínima. Segundo o Censo de 1940, cerca de 2/3 (67,2\%) dos mais de 41 milhões de brasileiros não sabiam ler ou escrever. De pouco mais de dois milhões (2.088.126) de diplomados de qualquer nível (elementar, médio ou superior), apenas 106.496 possuiam diploma de nível superior (IBGE 1940, p.30, Quadro 24).

Nessa "ilha de letrados" (Carvalho 1996) que ainda é o Senado, Direito é a formação predominante dos legisladores. Embora no regime de transição sua ocorrência tenha diminuído de $45,7 \%$ (primeiro ciclo político) para $38,1 \%$, ela continuará sempre a formação dominante na Casa. De 1986 até 2010 nada menos de um terço dos parlamentares da Câmara Alta ainda era formada em Direito (Costa \& Codato 2013). Essa característica, no entanto, está muito longe de ser universal. Não vale para a Irlanda e a Inglaterra, ou para a Espanha e a Alemanha, por exemplo ${ }^{10}$. Em 1994, nas eleições federais alemãs, graduados em Direito foram os mais bem-sucedidos, mas com apenas 14,3\% das cadeiras para o Parlamento, muito pouco acima dos profissionais da educação (14\%) e das profissões técnicas (13,3\%) (Wessels 1997, p.89). A Tabela 3 agrega as formações universitárias dos senadores brasileiros em quatro grandes classes: carreiras militares, carreiras técnicas, humanidades e diplomas tradicionais.

O valor do qui-quadrado obtido no cruzamento entre as duas variáveis indica que as variações nas distribuições não são independentes. A análise dos

Tabela 3 - Tipo de formação superior dos senadores brasileiros eleitos entre 1945 e 1990 por regime político (valores percentuais e resíduos padronizados ajustados)

\begin{tabular}{lccccc}
\hline \multirow{2}{*}{ Formação } & & \multicolumn{3}{c}{ Regime político } & \multirow{2}{*}{ Total } \\
\cline { 2 - 5 } & & Democracia populista & Ditadura militar & Regime de transição & \\
\hline Carreiras militares & $\%$ & 4,2 & 3,8 & 2,9 & $3,8 \%$ \\
& resíduos & 0,4 & 0 & $-0,5$ & \\
Carreiras técnicas $^{\mathrm{I}}$ & $\%$ & 13,7 & 14,3 & 26,2 & $16,9 \%$ \\
& resíduos & $-1,6$ & -1 & $\mathbf{2 , 9}$ & \\
Humanidades $^{\mathrm{II}}$ & $\%$ & 2,6 & 0,8 & 10,7 & $4,0 \%$ \\
& resíduos & $-1,3$ & $\mathbf{- 2 , 3}$ & $\mathbf{4}$ & \\
Diplomas tradicionais" $^{\text {III }}$ & $\%$ & 70,5 & 69,9 & 52,4 & $65,7 \%$ \\
& resíduos & 1,7 & 1,2 & $\mathbf{3 , 3}$ & \\
Sem diploma superior & $\%$ & 9,5 & 11,3 & 7,8 & $9,9 \%$ \\
& resíduos & 0 & 0,8 & $-0,7$ & 100 \\
\hline \multirow{2}{*}{ Total } & $\%$ & 100 & 100 & 100 & \\
\hline
\end{tabular}

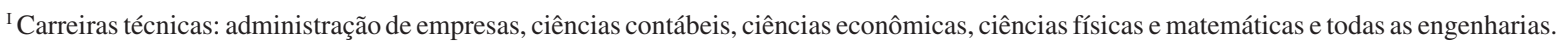

II Humanidades: arquitetura, ciências políticas e econômicas, ciências sociais, comunicação social, filosofia, história, letras, psicologia, teologia.

${ }^{\text {III }}$ Diplomas tradicionais: direito, medicina, odontologia.

Missing $=12 \operatorname{casos}(2,7 \%) \cdot \chi^{2} 27,618(0,001)$.

Fonte: os autores. 
${ }^{11}$ Resíduos padronizados revelam a diferença entre os valores observados e os valores esperados entre duas variáveis de um determinado grupo. Seu limite crítico é de + ou - 1,96 , isto é, quando acima de $+1,96$, indica alta propensão de concentração de casos na casela e, quando abaixo de $-1,96$, baixa propensão de concentração dos casos naquela casela. Ver Pestana e Gageiro (2008).

${ }^{12}$ Guido Mondim, eleito pela ARENA do Rio Grande do Sul em 1966, é formado em ciências políticas e econômicas pela Pontifícia Universidade Católica (PUC) do Rio Grande do Sul. resíduos nos permite fazer uma interpretação mais circunstanciada sobre esses resultados ${ }^{11}$.

O "bacharelismo" típico da vida política nacional, com a inflação de diplomados em Direito mas também em Medicina no primeiro e segundo períodos, podem explicar por que os senadores com diplomas tradicionais são a maioria na democracia populista $(70,5 \%)$ e na ditadura militar $(69,9 \%)$. Esse segmento ainda é maioria no regime de transição, mas a diminuição do seu peso relativo diante dos novos diplomados que chegam ao Senado se exprime de modo bem delineado no valor dos resíduos $(-3,3)$, que denotam a tendência negativa à concentração de casos de diplomas tradicionais entre os eleitos nos anos 1980.

Indivíduos formados em profissões técnicas não têm o aumento esperado na ditadura militar. $\mathrm{O}$ acréscimo em relação à democracia populista é insignificante e seus valores só irão dobrar (de 13,7\% para 26,2\%) no terceiro ciclo. A elevação desse grupo em comparação com os demais durante a transição também se confirma por meio dos resíduos positivos $(2,9)$.

Ao separar os senadores pelas suas áreas de formação, a mudança mais contrastante em termos relativos é dos diplomados na área de Humanidades. De único caso ${ }^{12}$ no período da ditadura (o que explica o resíduo negativo de -2,3) os formados em Hhumanidades sobrem para 11 casos no regime de transição; seu aumento proporcional às demais categorias aparece no valor dos resíduos $(4,0)$, que tem o número mais elevado da Tabela 3. A taxa de senadores que passaram por academias militares é praticamente a mesma nos três ciclos políticos (média de $3,7 \%$ ) e diminui a cada fase de regime, inclusive na ditadura militar.

Esses resultados sugerem que pelo menos sob o ponto de vista de suas áreas de formação, houve uma nítida alteração do perfil dos senadores eleitos no regime de transição. Isso pode ser um indício de que os mecanismos de recrutamento da elite senatorial foram sensíveis às alterações ambientais observadas durante a década de 1980, pois os eleitos com diplomas de Humanidades e de áreas técnicas passaram a exercer mandatos que nos regimes anteriores eram ocupados por senadores com diplomas tradicionais.

III.3. A estrutura etária do Senado

Em sistemas bicamerais, os Senados tendem a ser assembleias de indivíduos mais velhos quando comparados com as Câmaras Baixas. No Brasil, a cláusula que estipulou a idade mínima para ser eleito senador em todo esse intervalo de tempo não mudou: 35 anos.

O Gráfico 1 reúne informações sobre a faixa etária dos senadores entre 1945 e 1990. Ao longo das legislaturas, em nenhuma delas indivíduos com mais de 60 anos são a maioria entre os eleitos. A média de idade de todos os eleitos nesse período é de 54 anos. Portanto, a caracterização da Câmara Alta brasileira como uma casa de anciãos não encontra suporte nas evidências. Mas há outra ocorrência importante: o aumento de senadores mais jovens no regime de transição: eles são praticamente $45 \%$ da Casa entre 1982 e 1990.

Na fase de transição para o regime democrático, o Senado não apenas se torna mais jovem, mas os recrutados em 1982 têm a menor média de idade: apenas 49 anos. Durante a democracia de 1946 o maior contingente de senadores estava no intervalo de 51 a 60 anos (39\%). Porém, somadas as duas primeiras faixas de idade, $74 \%$ dos representantes estão abaixo dos 60 anos. Na ditadura militar a Casa envelhece: quando comparado com o ciclo político anterior, quase um terço dos indivíduos tem mais de sessenta anos de idade. 


\section{Empreendimento político e configuração das carreiras senatoriais}

${ }^{13}$ Por "cargos públicos" nos referimos aos cargos eletivos no Executivo e no Legislativo nos três níveis da federação (município, estado e união federal) e, além desses, os cargos de nomeação política (como secretarias e cargos de direção em autarquias públicas). Não consideramos cargos ocupados pela via de concurso público (como é o caso de juízes, diplomatas e militares de carreira).

Igualmente, cargos no mundo associativo como diretores de sindicatos não foram considerados. Trata-se de enfatizar a ocupação de posições derivada da competição político-partidária.
Apresentamos a seguir algumas curvas com o comportamento de indicadores de carreira política dos senadores estudados. O Gráfico 2 mostra a evolução do número médio de posições políticas anteriores à chegada ao Senado Federal. Elaboramos essa média a partir da soma de todos os cargos públicos ${ }^{13}$ divididos pelo número de senadores de cada eleição.

O Gráfico 2 ressalta que os perfis de carreira respondem às alterações nas regras de competição com dois períodos bem identificáveis: antes e depois de 1966. Com a adoção do pluripartidarismo em 1945 há uma tendência de crescimento lento, mas constante do indicador "média de posições públicas" antes de se chegar ao Senado. A segunda fase, por outro lado, é bem errática. A

Gráfico 1 - Classes de idade dos senadores brasileiros eleitos entre 1945 e 1990 por regime político (em percentuais)

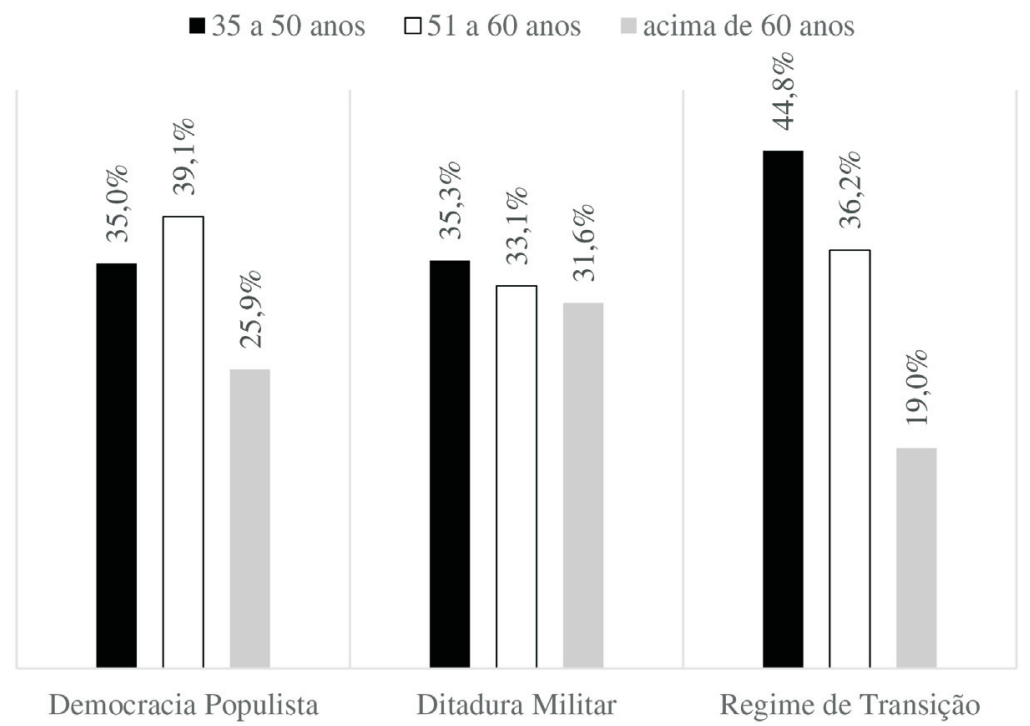

Fonte: os autores.

Gráfico 2 - Número médio de posições públicas ocupadas antes da chegada ao Senado Federal, Brasil, 1945-1990

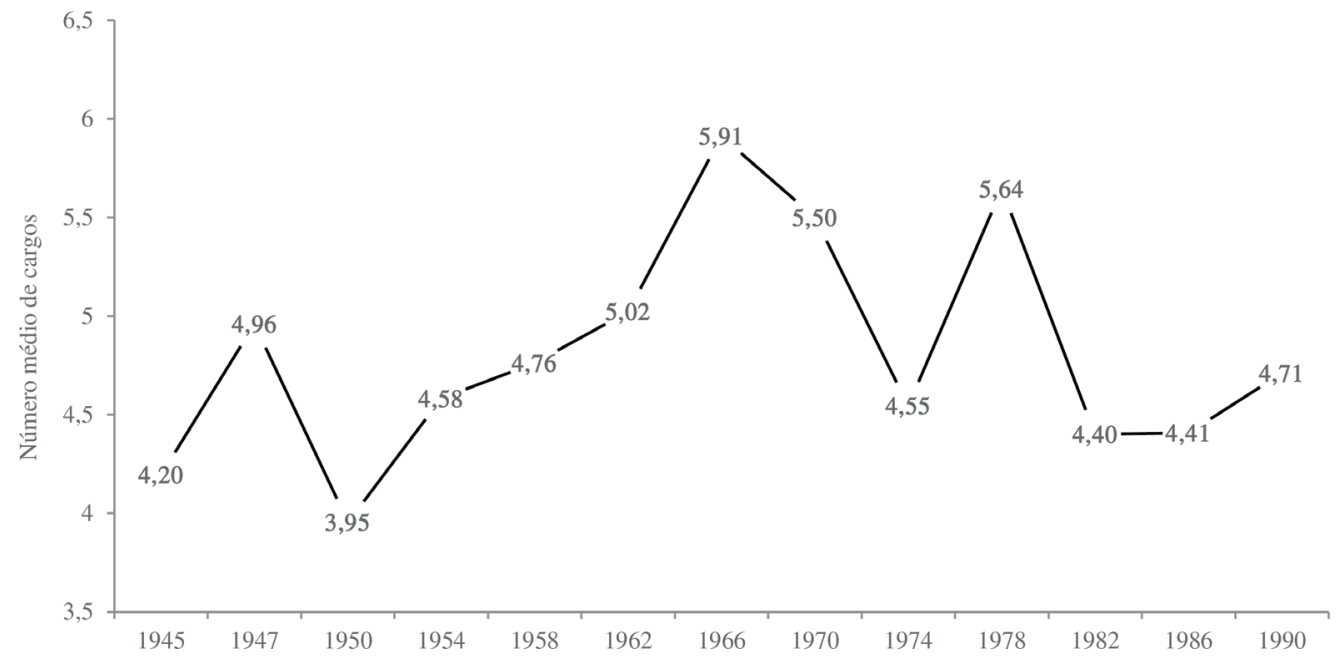

Fonte: os autores. 
${ }^{14}$ Em um estudo sobre os perfis de carreira dos senadores brasileiros na primeira república, Massimo e Costa examinam esse fenômeno tendo como referência o conceito da "circulação política" (Massimo \& Costa 2015).

${ }^{15} \mathrm{O}$ biônico mais experiente era Ernani Amaral Peixoto (MDB-RJ), com 12 cargos prévios. Em seu verbete no DHBB lê-se o seguinte: "Embora se houvesse manifestado desde o início contra a instituição do "senador biônico" e disposto inclusive a se afastar da política ao término do mandato, Amaral Peixoto considerou-se obrigado a aceitá-la por força da pressão de seus correligionários e do pedido de Nélson Carneiro para que deixasse para ele o cargo de senador direto, temeroso de que seu nome não fosse sufragado na convenção." (s.p.). Nelson Carneiro também foi eleito no pleito de 1978. quebra do sistema em 1965 e o bipartidarismo produzirão efeitos em 1970 e em 1974; a intervenção em 1977 irá impactar em 1978 e a volta do pluripartidarismo em 1979 produzirá nova oscilação no padrão de carreira.

O primeiro intervalo democrático apresenta duas características: as eleições de 1945 e de 1947 foram dominadas por indivíduos relativamente experientes e em seguida houve uma típica eleição de renovação (1950), com uma queda na média de cargos ocupados, indicando uma onda de políticos um pouco menos experimentados.

Se recordarmos que os políticos que se criaram no Estado Novo (19371945) foram personagens centrais da reabertura democrática (Souza 1976), faz sentido que seus quadros tenham dominado as eleições legislativas de 1945 e 1947. Por outro lado, a ampliação da competição política e as diversas organizações partidárias que se originaram a partir de então se faria sentir na eleição seguinte (1950), na qual observaremos a diminuição da média de cargos prévios $(3,95)$. Mas o que chama a atenção é a tendência constante de crescimento da média de cargos prévios até 1966. A democracia populista promoveu um aumento paulatino da diversificação quantitativa ${ }^{14}$ das carreiras dos senadores eleitos, saindo de uma média de 4,2 cargos e chegando a 5,91 na primeira eleição do bipartidarismo.

A partir de 1966, com a introdução do regime de dois partidos, a tendência de crescimento gradual e constante se inverte, até se chegar ao menor valor desse ciclo, 4,55 em 1974. A conjuntura especial da eleição para o Senado em 1974 produziu uma queda na quantidade média de cargos ocupados, especialmente por conta do ingresso de muitos senadores do MDB, que embora não fossem políticos sem experiência, não tinham o estoque de cargos dos políticos dos arenistas. Na eleição de 1978 - marcada pela figura do "senador biônico", introduzido em 1977 - a maioria arenista é retomada e, com isso, os assentos serão ocupados por políticos com alta circulação em diversos postos políticos (média de 5,64 cargos). Isolando o grupo dos 22 "senadores biônicos", essa média se eleva para 6,04 $\operatorname{cargos}^{15}$.

A eliminação da eleição indireta para parte do Senado e a reorganização partidária de 1979 produziu uma nova queda no indicador em 1982 (4,4 cargos), mostrando que o padrão de carreira da elite legislativa irá oscilar em direção à menor experiência quando comparada aos períodos anteriores.

O Gráfico 3 apresenta uma outra forma de analisar o perfil da carreira ao longo das 13 eleições. Trata-se da disposição do tempo médio de carreira política prévia (medido em anos) para todos os senadores eleitos, independentemente do partido ao qual pertencia.

Assim como visto no Gráfico 2, há situações diferentes entre os grandes ciclos recobertos pela análise. A despeito das oscilações para baixo em 1950 (muito acentuada) e em 1958 (significativa), o tempo médio de carreira no período pluripartidário, que repercutirá na eleição de 1966, cresce progressivamente até o pico máximo de 25 anos. Nas eleições seguintes, o tempo de carreira desses agentes políticos tende sempre a diminuir e de forma importante: ele irá de 25 anos nas primeiras eleições do bipartidarismo, em 1966, a apenas 17 anos até a chegada à Câmara Alta em 1990, indicando uma inflexão naquele padrão de crescimento da expertise política dos senadores. O grande ruído aqui é o ano de 1978. A imposição das eleições indiretas para 1/3 da Casa pelo regime ditatorial em 1977 eleva o tempo médio a quase 25 anos de vida pública. Essa reforma, que pretendia um controle mais rígido sobre a competição política, elitiza a disputa, pressionando os partidos a compor as chapas com políticos mais experientes. 
Gráfico 3 - Tempo médio da carreira política em anos antes da chegada ao Senado Federal, Brasil, 1945-1990

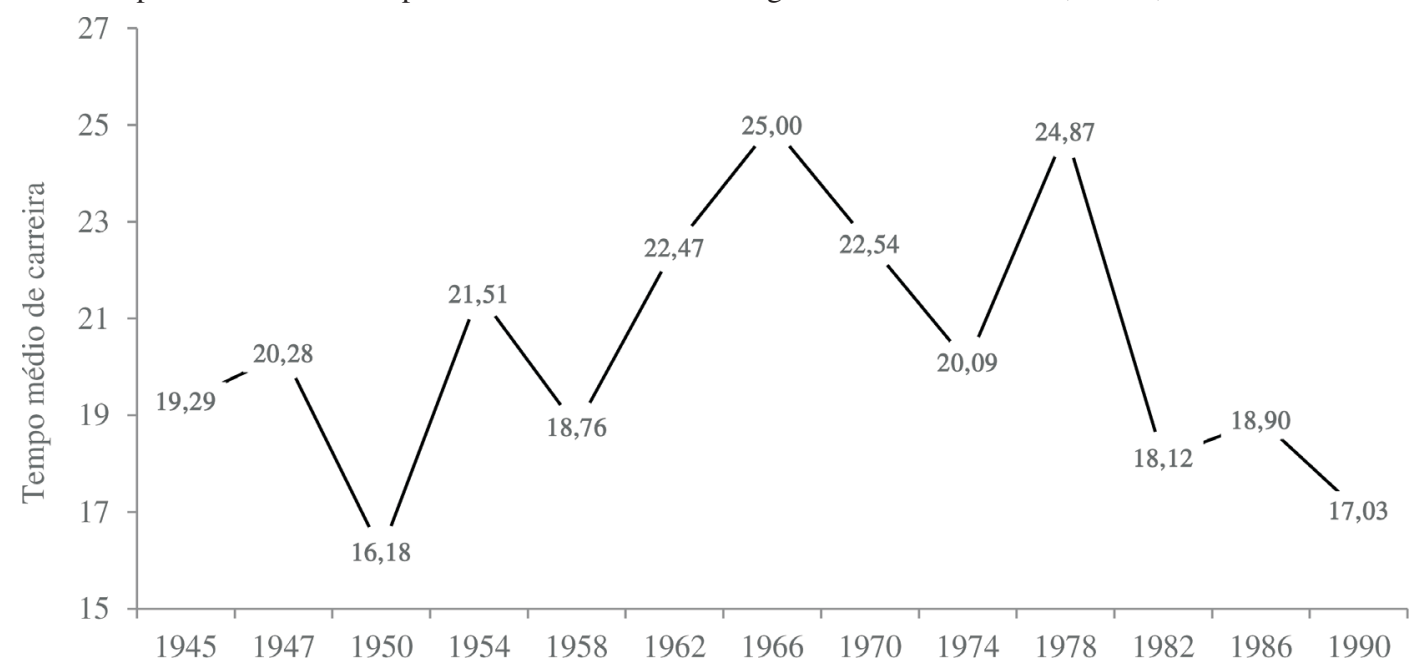

Fonte: os autores.

Quando observado do ângulo dos partidos (e do regime que os instituíram), as carreiras mostram contraste entre partidos do mesmo regime e entre os diferentes regimes. A Tabela 4 registra, na primeira linha, o tempo médio de carreira na vida pública dos eleitos pelos partidos. Na parte inferior separamos as médias do tempo de carreira em quatro grupos. Os menores valores estão abaixo do primeiro quartil (média até o $1^{\circ}$ quartil), e os valores do tempo das carreiras mais extensas se situam entre o terceiro quartil e o limite superior (média do quartil superior). As médias até o $2^{\circ}$ e $3^{\circ}$ quartil registram as situações intermediárias.

No primeiro ciclo pluripartidário (democracia populista), as maiores diferenças se dão entre o tempo de carreira dos trabalhistas em relação aos demais partidos grandes (PSD e UDN). O PTB teve os senadores com as carreiras mais longas (23 anos até o Senado). As dificuldades que o PTB encontrou para montar uma estrutura política em âmbito nacional (Soares 1981) podem ter se refletido na eleição de indivíduos mais experientes: entre os senadores com carreiras curtas, os eleitos pelo PTB já tinham em média 10,5 anos na vida pública, o dobro dos que se elegeram pelo PSD $(4,29)$ ou pela UDN $(5,71)$.

Tabela 4 - Tempo médio de carreira dos senadores eleitos por partido no Brasil, 1945-1990 (em anos)

\begin{tabular}{|c|c|c|c|c|c|c|c|c|c|c|}
\hline & \multicolumn{4}{|c|}{ Democracia populista } & \multicolumn{2}{|c|}{ Ditadura militar } & \multicolumn{4}{|c|}{ Regime de transição } \\
\hline & PSD & PTB & UDN & Outros $^{\mathrm{I}}$ & ARENA & MDB & PDS & PFL & PMDB & Outros ${ }^{\text {II }}$ \\
\hline Tempo de carreira médio & 20,36 & 23 & 20,72 & 16,88 & 23,25 & 23,59 & 18,61 & 22 & 17,81 & 15,56 \\
\hline Média até o $1^{\circ}$ quartil & 4,29 & 10,50 & 5,71 & 4,50 & 10,11 & 7,00 & 6,80 & 2,33 & 4,56 & 1,75 \\
\hline Média até o $2^{\circ}$ quartil & 16,77 & 18,71 & 16,45 & 13,22 & 19,79 & 17,22 & 14,80 & 19,40 & 13,64 & 15,17 \\
\hline Média até o $3^{\circ}$ quartil & 24,48 & 26,50 & 23,77 & 20,22 & 28,39 & 28,78 & 20,25 & 27,67 & 21,38 & 23,67 \\
\hline Média do quartil superior & 36,10 & 38,43 & 38,83 & 29,63 & 38,30 & 41,50 & 36,50 & 40,33 & 33,79 & 26,67 \\
\hline
\end{tabular}

I As organizações agregadas aqui são as seguintes: Partido Socialista Brasileiro (PSB), Partido Social Trabalhista (PST), Partido Trabalhista Nacional (PTN), Partido Democrata Cristão (PDC), Movimento Trabalhista Renovador (MTR), Partido Republicano (PR), Partido da Representação Popular (PRP), Partido Proletário do Brasil (PPB), Partido Social Progressista (PSP), Partido Comunista Brasileiro (PCB), Partido Libertador (PL) e Partido Popular Sindicalista (PPS).

II As organizações agregadas aqui são as seguintes: Partido Democrata Cristão (PDC), Partido Trabalhista Brasileiro (PTB), Partido da Social Democracia Brasileira (PSDB), Partido Democrático Trabalhisa (PDT), Partido dos Trabalhadores (PT), Partido Democrata Cristão (PDC), Partido da Mobilização Nacional (PMN), Partido da Renovação Nacional (PRN), Partido Progressista Reformador (PPR).

Fonte: os autores. 
Outro achado se refere ao tempo de carreira dos senadores eleitos pelos pequenos partidos. Eles tiveram médias muito menores nas seis eleições do regime democrático-populista que os demais (menos de 17 anos). Com a reintrodução, em 1945, das eleições legislativas após a ditadura do Estado Novo, partidos novos e pequenos serviram como instrumento para que velhas raposas políticas criassem suas próprias máquinas eleitorais, evitando assim o confronto com líderes poderosos em máquinas fortemente controladas. No momento seguinte, contudo, esses partidos menores devem ter servido como alternativa para que novas lideranças, menos experientes, se elegessem mais facilmente. A comparação entre as médias do quartil superior revela essa diferença: os mais experientes que se elegeram por outros partidos tiveram um tempo de carreira médio de 29,63 anos, contra 36,1 anos do PSD, 38,43 anos do PTB e 38,83 anos entre os udenistas com carreira mais longa. A fragmentação do sistema partidário aumentou assim as chances de ingresso no Senado de políticos com carreira menos extensa.

Padrão bem distinto pode ser observado no regime ditatorial-militar. Se compararmos, de um lado, a média do PSD (20 anos de carreira) e a da UDN (21 anos) com as médias da ARENA (23 anos) e do MDB (quase 24 anos), de outro, concluiremos que o ciclo bipartidário forçou o recrutamento de políticos mais experimentados e, como vimos no Gráfico 1 , mais velhos.

O aumento da extensão da carreira política dos senadores vencedores nas eleições sob o bipartidarismo nas duas legendas criadas pela ditadura militar foi fruto da incorporação às novas siglas de muitas lideranças dos partidos do regime anterior e, especialmente, das lideranças mais experimentadas e mais poderosas. Como o MDB enfrentou muitas dificuldades para obter cadeiras senatoriais em todas as eleições que não a de 1974 (Madeira 2007), suas bancadas tiveram, por isso mesmo, as maiores médias de carreira de todos os partidos, indicando que o estrangulamento pelo qual o sistema passou foi responsável pelo alijamento de políticos sem muita experiência. Entre os senadores eleitos pela ARENA, os que possuíam carreiras mais curtas tinham em média 10,11 anos em postos públicos (entre os eleitos pelo MDB a média era de 7 anos). Os mais longevos do MDB se elegeram com 41,5 anos de experiência em cargos públicos, o valor mais elevado da Tabela 4. Esse dado também reforça a conclusão de que no regime bipartidário a agremiação de oposição elegeu candidatos experimentados na vida política.

A partir de 1982, sob o regime de renovação dos partidos políticos nacionais, há também uma renovação da elite política senatorial, cuja evidência é a queda brusca do tempo de carreira dos vitoriosos do PMDB (18 anos) e dos outros partidos de oposição (apenas 15,5 anos). Observando apenas os casos situados até o primeiro quartil, vemos valores médios bastante inferiores em relação ao período anterior. No PMDB, por exemplo, os senadores eleitos a partir da década de 1980 tinham em média 4,56 anos de experiência (contra sete anos de carreira antes da chegada ao Senado pelo MDB). Na outra ponta, quando isolamos o grupo mais longevo (o que se situa no quartil superior), a média do tempo de carreira pelos outros partidos é de 26,67 anos, o menor valor entre os senadores mais experientes desde 1945. A renovação parece ter sido mais clara nos outros partidos do regime de transição.

O Gráfico 4 mostra qual o último tipo de cargo antes da conquista da cadeira no Senado por diferentes regimes. Consideramos aqui o âmbito político do posto ocupado e o vetor de sua escolha, isto é, se local/estadual, federal ou altos cargos federais. Os atributos da variável são os seguintes: (i) début no Senado: sem experiência em cargos públicos eletivos no Executivo e Legislativo nos três níveis da federação e, além destes, sem experiência em cargos de nomeação política; (ii) cargo regional: vereadores, prefeitos, secretários estaduais ou car- 
Gráfico 4 - Nível do último cargo ocupado antes da chegada ao senado brasileiro em cada regime político, Brasil, 1945-1990 (resíduos padronizados ajustados)

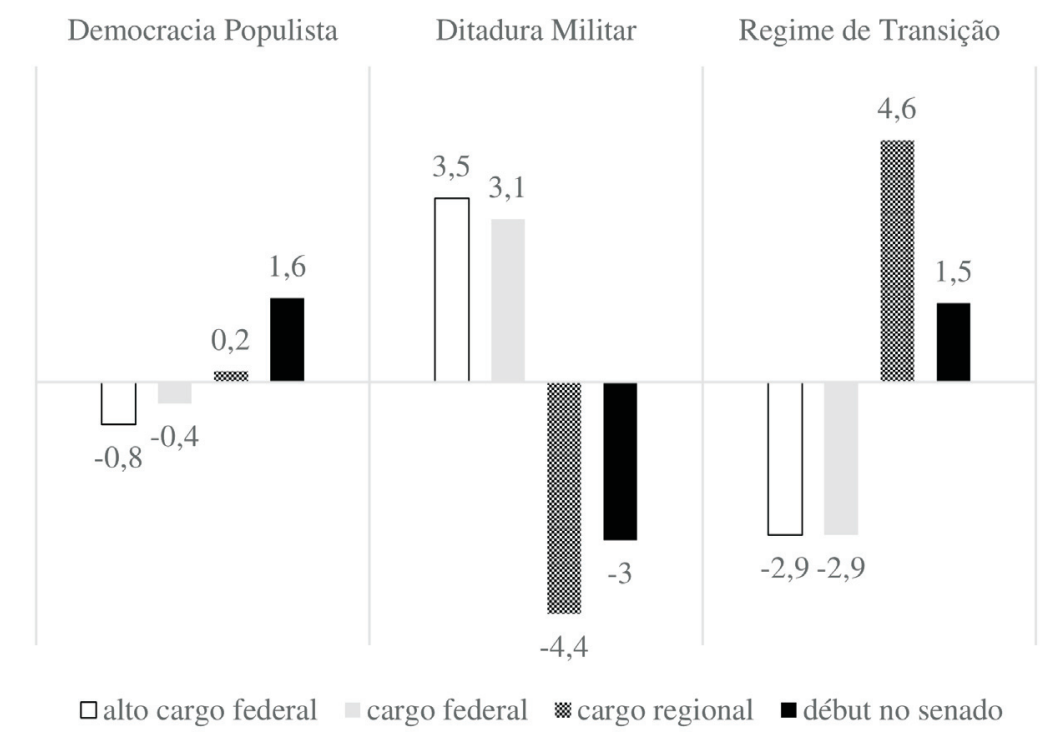

$\chi^{2}: 48,724(0,000)$.

Fonte: os autores.

gos de segundo escalão na burocracia estadual, deputados estaduais e governadores a partir de 1950; (iii) cargo federal: deputados federais e cargos de nomeação na burocracia federal em segundo escalão; (iv) alto cargo federal: governadores nas eleições de 1945 e 1947 (incluídos aqui por conta da sua indicação pelo Presidente da República durante o Estado Novo) e durante a ditadura militar, ministros, vice-presidente e presidente da República.

Considerados todos os senadores e todos os partidos separados por regimes, não há um tipo de cargo predominante que facilite ou esteja na origem da chegada ao Senado (os resíduos padronizados ajustados estão entre o intervalo crítico). Já o segundo ciclo político está associado a cargos federais (deputados e cargos burocráticos nacionais) e a altos cargos federais (governadores e ministros). Também no bipartidarismo não há concentração de agentes políticos que estreiam no Senado (resíduos padronizados ajustados de -3,0) e cargos regionais não são um trunfo político $(-4,4)$. O terceiro ciclo, com a retomada do pluripartidarismo, é o regime em que os cargos em nível regional estarão muitíssimomais valorizados (resíduos de 4,6), em prejuízo das posições nacionais.

Vejamos agora como esses dados estão distribuídos pelas agremiações dos senadores. Os números da Tabela 5 revelarão alterações nas vias políticas de acesso ao Senado conforme os regimes partidários e os partidos em cada regime.

Durante a democracia populista, os senadores do Partido Social Democrático (PSD) foram recrutados a partir das posições federais que ocuparam (64\%), com destaque para os quase $19 \%$ dos seus quadros provenientes dos altos cargos federais (16 representantes). O PTB concentrou-se em cargos federais e também estaduais (a soma das duas colunas é igual a $89 \%$ dos senadores da agremiação, ou 63 dos 85 senadores do partido). A União Democrática Nacional (UDN), por sua vez, teve pouquíssimos senadores vindos da alta administração federal, como esperável, apenas $6 \%$ ou três dos seus 50 no período. Mas foi, 
Tabela 5 - Nível do último cargo ocupado pelos eleitos antes da chegada ao senado, por partido, conforme o regime político no Brasil, 1945-1990

\begin{tabular}{lcccccc}
\hline & Partido & Alto cargo federal & Cargo federal & Cargo regional & Début no senado & Total \\
\hline Democracia populista & PSD & $18,8 \%$ & $45,9 \%$ & $28,2 \%$ & $7,1 \%$ & $100,0 \%$ \\
& PTB & $7,1 \%$ & $64,3 \%$ & $25,0 \%$ & $3,6 \%$ & $100,0 \%$ \\
& UDN & $6,0 \%$ & $50,0 \%$ & $34,0 \%$ & $10,0 \%$ & $100,0 \%$ \\
& outros & $5,9 \%$ & $55,9 \%$ & $29,4 \%$ & $8,8 \%$ & $100,0 \%$ \\
& Total & $11,7 \%$ & $51,3 \%$ & $29,4 \%$ & $7,6 \%$ & $100,0 \%$ \\
\hline \multirow{2}{*}{ Ditadura militar } & ARENA & $27,5 \%$ & $64,7 \%$ & $7,8 \%$ & $3,9 \%$ & $100,0 \%$ \\
& MDB & $2,9 \%$ & $58,8 \%$ & $3,3 \%$ & $2,9 \%$ & $100,0 \%$ \\
& Total & $21,3 \%$ & $63,2 \%$ & $14,7 \%$ &, $7 \%$ & $100,0 \%$ \\
\hline \multirow{2}{*}{ Regime de transição } & PDS & $5,6 \%$ & $27,8 \%$ & $61,1 \%$ & $5,6 \%$ & $100,0 \%$ \\
& PFL & $7,1 \%$ & $42,9 \%$ & $35,7 \%$ & $14,3 \%$ & $100,0 \%$ \\
& PMDB & $5,3 \%$ & $47,4 \%$ & $40,4 \%$ & $7,0 \%$ & $100,0 \%$ \\
& outros & & $25,0 \%$ & $62,5 \%$ & $12,5 \%$ & $100,0 \%$ \\
& Total & $4,8 \%$ & $40,0 \%$ & $46,7 \%$ & $8,6 \%$ & $100,0 \%$ \\
\hline
\end{tabular}

$\chi^{2}: 85,109(0,000)$.

Fonte: os autores.

percentualmente, quem mais teve políticos que estreiaram diretamente no Senado: cinco. Essa informação pode parecer contraditória se nos recordamos o elevado tempo médio de carreira prévia dos udenistas, quase 21 anos (Tabela 4), e a existência desses $10 \%$ de novatos. Entretanto, isto revela justamente aquilo que Benevides (1981) chamou a atenção, a existência, num país federal, de várias UDNs. O partido era formado por antigos líderes do Estado Novo como Artur Bernardes em Minas e também por políticos como Durval Rodrigues da Cruz, sergipano que conquista uma cadeira no Senado aos 43 anos sem experiência em cargos eletivos.

Na ditadura militar, um fenômeno a ser enfatizado é o número mínimo de senadores sem qualquer cargo prévio na política institucional antes de chegar à Casa. Ao que tudo indica, o bipartidarismo compulsório, ao diminuir dentro dos próprios partidos as vagas para a disputa eleitoral, restringiu as chances dos competidores politicamente inexperientes. Em 136 senadores eleitos no período, apenas um, do MDB, tinha esse perfil (Leite Chaves, do Paraná).

Durante o ciclo político autoritário, a estratégia do partido de oposição diferiu muito da do partido do governo. Enquanto a ARENA buscou seus senadores em cargos federais (92\%), com destaque para altos cargos federais por nomeação (ministros e governadores), o MDB teve muitos senadores que haviam sido deputados federais (quase $60 \%$ da sua bancada, ou 12 dos 34 eleitos), mas também muito mais senadores com experiência regional (35\%) do que os arenistas (apenas 8\%).

No regime de transição para a democracia, com a volta do pluripartidarismo e a mudança nas condições de competição no jogo eleitoral, será agora o PDS, herdeiro direto da ARENA, o partido com mais representantes que provieram dos cargos regionais ( 11 dos seus 18 senadores ou $61 \%$ da bancada). Esse será também o perfil do grupo que venceu as eleições pelos partidos menores: 62,5\% dos políticos nessa modalidade para as outras agremiações. O PFL, por sua vez, será o partido com o maior número de debutantes no Senado: 14\%. O PMDB, o partido continuador do MDB, que se tornou a maior agremiação do sistema, com 57 dos 105 senadores eleitos entre 1982 e 1990, continuará, todavia, com o 
mesmo perfil de recrutamento da sigla originária, como se pode ver pela Tabela 4.

\section{Conclusões}

Este artigo partiu da seguinte indagação: quais os impactos produzidos pelas mudanças de regime político sobre o perfil social e o sobre os padrões de carreira dos senadores eleitos no Brasil nas 13 disputas ocorridas entre 1945 e 1990? As transformações bruscas e sucessivas de regime partidário nesse intervalo de tempo (pluripartidarismo, bipartidarismo e novamente pluripartidarismo) teriam produzido algum efeito visível, visto que, com exceção da eleição de 1978, as regras para concorrer ao cargo - voto majoritário em turno único, distrito estadual, disputa alternada de uma e duas cadeiras - permaneceram as mesmas?

Nosso estudo indica que sim. Os achados desta pesquisa podem ser resumidos em seis proposições

1. Quando se olha para o background social dos senadores, o que se vê não são grandes mudanças em sintonia nem com as profundas transformações pelas quais o país passou em quase meio século (urbanização acelerada, industrialização capitalista, modernização do mercado produtivo e remodelagem da estrutura de classes), nem com o abalo político representado pela quebra do regime em 1964 e pela transformação repentina do sistema de partidos em 1965. Não há modificações bruscas nos indicadores sobre "profissões" de origem, o que não significa que tenham permanecido inalterados. Duas novidades merecem destaque: a diminuição constante do contingente de senadores oriundos das carreiras jurídicas e a hegemonia, ao final, dos empresários (Tabela 2). Assim como na Câmara dos Deputados do Brasil, as duas categorias de profissões que dominam todo o período estudado são sempre os advogados e os empresários, esses últimos se firmando como um contingente muito expressivo (Tabela 2).

2. No caso da formação escolar, o "capital cultural” continua sendo uma variável decisiva no jogo político brasileiro. Todavia, o contingente de formados em Direito, ainda a grande maioria dos senadores, vem caindo continuamente e os egressos das carreiras técnicas vão aumentando quase na mesma proporção (Tabela 3).

3. Uma das variações mais significativas durante esse intervalo é a da estrutura etária: com o passar do tempo e a sucessão de disputas, o Senado brasileiro vai se tornando cada vez mais jovem (Gráfico 1). No último ciclo político, $45 \%$ dos senadores estão concentrados na faixa entre 35 e 50 anos de idade, um padrão normalmente verificado nas Câmaras Baixas. Esse dado pode indicar que houve um processo de renovação da classe política nacional graças à reintrodução do pluripartidarismo e à possível depuração das velhas lideranças, tal como se encontrou no caso da Câmara dos Deputados (Marenco dos Santos 2000).

4. No que se refere aos itinerários políticos, as evidências apontaram para dois processos relacionados diretamente aos sobressaltos institucionais. $\mathrm{O}$ aumento gradual no tempo médio das trajetórias políticas que precedia a chegada ao Senado foi interrompido com o golpe de 1964, provocando um salto para cima no tempo de carreira dos parlamentares sob o governo militar em 1966 (Gráfico 3). Mas a partir daí, a carreira até a Câmara Alta se torna cada vez menor, com a exceção do ano de 1978, onde vigorou a regra de eleição indireta para um terço do Senado ("senadores biônicos"). Com a reintrodução do pluripartidarismo, por sua vez, a extensão da carreira prévia torna a diminuir, quase se igualando aos patamares da democracia populista.

5. A segunda consequência do golpe de 1964 e da imposição do regime bipartidário em 1965 se refere ao tipo de recrutamento das agremiações criadas pelo governo autoritário. O MDB recrutará os seus senadores entre os políticos altamente experientes, sintoma da permanência de antigos nomes da política nacional, com quase 24 anos de trajetória pública (Tabela 4), exceto em 1974, 
quando elegeu candidatos cujas carreiras eram, senão curtas, muito menos longevas que a dos seus concorrentes.

6. De um modo geral, a mudança de regime político e a reconfiguração partidária com a introdução do bipartidarismo produziram efeitos muito distintos daqueles observados nos cargos nomeados (i.e., não eleitos) pelos governos militares, como ministros de Estado e governadores (Samuels \& Abrucio 2000; Santos 1971). Os dois eventos transformaram uma elite parlamentar razoavelmente treinada em uma elite muito mais experiente, a despeito das intenções declaradas dos militares de renovar a classe politica nacional. Como a luta eleitoral ficou canalizada em apenas dois partidos, a disputa política, na ditadura, terminou por se restringir aos políticos mais velhos (Gráfico 1).

É possível sustentar então que o Legislativo funcionou, no regime ditatorial-militar, como um espaço de acomodação daquelas facções das elites políticas convencionais que os militares afirmavam ter aposentado. Além disso, os resultados parecem confirmar o protagonismo que a política estadual assumiu no Brasil durante o regime de transição. O nível do último cargo ocupado antes da conquista da cadeira no Senado (Gráfico 4) indica que os mecanismos de recrutamento valorizaram a experiência obtida em nível regional.

Adriano Codato (adriano@ufpr.br) é doutor em Ciência Política pela Universidade Estadual de Campinas (Unicamp), professor do Programa de Pós-Graduação em Ciência Política da Universidade Federal do Paraná (UFPR), e pesquisador do Núcleo de Pesquisa em Sociologia Política Brasileira (NUSP-UFPR). Vínculo Institucional: Programa de Pós-Graduação em Ciência Política, UFPR, Curitiba, PR, Brasil.

Luiz Domingos Costa (luizdomingos@gmail.com) é doutorando no Programa de Pós-Graduação em Ciência Política da Universidade Federal do Paraná (UFPR), professor de Ciência Política na Pontíficie Universidade Católica (PUC-PR), no Centro Universitário Internacional (Uninter) e pesquisador do Núcleo de Pesquisa em Sociologia Política Brasileira (NUSP-UFPR). Vínculo Institucional: Programa de Pós-Graduação em Ciência Política, UFPR, Curitiba, PR, Brasil.

Lucas Massimo (lucasmassimo@gmail.com) é doutorando no Programa de Pós-Graduação em Ciência Política da Universidade Federal do Paraná (UFPR), professor de Ciência Política no Centro Universitário Internacional (Uninter) e pesquisador do Núcleo de Pesquisa em Sociologia Política Brasileira (NUSP-UFPR). Vínculo Institucional: Programa de Pós-Graduação em Ciência Política, UFPR, Curitiba, PR, Brasil.

Flavio Heiz (fmheinz@gmail.com) é doutor em História e Sociologia do Mundo Contemporâneo pela Université de Paris X (Nanterre), professor visitante do Programa de Pós-Graduação em Ciência Política da Universidade Federal do Paraná (UFPR) e pesquisador do Núcleo de Pesquisa em Sociologia Política Brasileira (NUSP-UFPR). Vínculo Institucional: Programa de Pós-Graduação em Ciência Política, UFPR, Curitiba, PR, Brasil.

\section{Referências}

Abreu, A.A. et al. eds., 2001. Dicionário histórico-biográfico brasileiro, Rio de Janeiro: Centro de Pesquisa e Documentação de História Contemporânea do Brasil/Fundação Getúlio Vargas.

Araújo, P.M., 2011. Recrutamento parlamentar para o Senado e o perfil dos senadores brasileiros, 1989-2006. Política Hoje, 20(2), pp.550-580.

Benevides, M.V.M., 1981. A UDN e o udenismo (ambiguidades do liberalismo brasileiro). Rio de Janeiro: Paz e Terra.

Best, H. \& Cotta, M., 2000. Parliamentary Representatives in Europe 1848-2000. Legislative Recruitment and Careers in Eleven European Countries. Oxford: Oxford University Press.

Best, H. \& Edinger, M., 2005. Converging Representative Elites in Europe? An Introduction to the EurElite Project. Czech Sociological Review, 41(3), pp.499-510.

Braga, S.S., 1998. Quem foi quem na Assembléia Constituinte de 1946: um perfil socioeconômico e regional da Constituinte de 1946. Brasília: Centro de Documentação e Informação da Câmara dos Deputados.

Canton, D., 1966. El Parlamento Argentino en épocas de cambio: 1890, 1916 y 1946. Buenos Aires: Editorial del Instituto.

Carvalho, J.M., 1996. A construção da ordem: a elite política imperial; Teatro de sombras: a política imperial. $2^{\mathrm{a}}$ ed. Rio de Janeiro: Editora UFRJ/Relume-Dumará.

Cervi, E.U.; Costa, L.D.; Codato, A.; Perissinotto, R., 2015. Dinheiro, profissão e partido político: a vitória na eleição para deputado federal no Brasil em 2010. Sociedade e Estado, 30(1), pp.189-205. DOI: 10.1590/s0102-69922015000100011

Codato, A., 2015. Estado Novo no Brasil: um estudo da dinâmica das elites políticas regionais em contexto autoritário. Dados, 58(2), pp.305-330. DOI: 10.1590/00115258201545 
Codato, A., 2005. Uma história política da transição brasileira: da ditadura militar à democracia. Revista de Sociologia e Política, (25), pp.83-106. DOI: 10.1590/s0104-44782005000200008

Costa, L.D. \& Codato, A., 2013. Profissionalização ou popularização da classe política brasileira? Um perfil dos Senadores da República. In A. Marenco dos Santos \& A. Codato, eds. Os Eleitos: representação e carreiras políticas em democracias. Porto Alegre: Editora da UFRGS.

Costa, P.R.N., 2014. Elite empresarial e elite econômica: o estudo dos empresários. Revista de Sociologia e Política, 22(52), pp.47-57. DOI: 10.1590/1678-987314225204

Costa, P.R.N.; Costa, L.D. \& Nunes, W., 2014. Os senadores-empresários: recrutamento, carreira e partidos políticos dos empresários no Senado brasileiro (1986-2010). Revista Brasileira de Ciência Política, 14, pp.227-253. DOI: $10.1590 / 0103-335220141409$

Cotta, M. \& Tavares de Almeida, P., 2007. From Servants of the State to Elected Representatives: Public Sector Background among Members of Parliament. In M. Cotta \& H. Best, eds. Democratic Representation in Europe: Change, Diversity and Convergence. Oxford: Oxford University Press.

Dolhnikoff, M., 2005. O pacto imperial: origens do federalismo no Brasil do século XIX. São Paulo: Globo.

Fleischer, D.V., 1973. O trampolim político: mudanças nos padrões de recrutamento político em Minas Gerais. Revista de Administração Pública, 7(1), pp.99-116.

, 1981. O pluripartidarismo no Brasil: dimensões sócio-econômicas e regionais do recrutamento legislativo, 1946-1967. Revista de Ciência Política, 24(01), pp.49-75.

Fukai, S.N. \& Fukui, H., 1992. Elite Recruitment and Political Leadership. PS: Political Science and Politics, 25(1), pp.25-36. DOI: $10.2307 / 419571$

Gené, M., 2014. Sociología política de las elites. Apuntes sobre su abordaje a través de entrevistas. Revista de Sociologia e Política, 22(52), pp.97-119. DOI: 10.1590/1678-987314225207

Hora, R., 2014. La elite económica Argentina, 1810-1914. Revista de Sociologia e Política, 22(52), pp.27-46. DOI: $10.1590 / 1678-987314225203$

Lemos, L.B. ed., 2008. O Senado Federal brasileiro no pós-Constituinte. Brasília: Senado Federal/UNILEGIS.

Llanos, M. \& Sánchez, F., 2006. Council of Elders?: The Senate and Its Members in the Southern Cone. Latin American Research Review, 41(1), pp.133-152. DOI: 10.1353/lar.2006.0011

Love, J.L., 1982. A locomotiva: São Paulo na federação brasileira, 1889-1937. Rio de Janeiro: Paz e Terra.

Madeira, R.M., 2007. Integração vertical e estabilidade de carreiras políticas: uma análise da trajetória política dos deputados federais da Arena gaúcha. Política \& Sociedade, 6(10), pp.243-273. DOI: 10.5216/sec.v7i2.984

Marenco dos Santos, A., 1997. Nas fronteiras do campo político: Raposas e outsiders no Congresso Nacional. Revista Brasileira de Ciências Sociais, 12(33), pp.87-101.

2000. Não se fazem mais oligarquias como antigamente: recrutamento parlamentar, experiência política e vínculos partidários entre deputados brasileiros (1946-1998). Porto Alegre: UFRGS.

Di Martino, M., 2009. A política como profissão: análise da circulação parlamentar na Câmara dos Deputados (1946-2007). São Paulo: Universidade de São Paulo.

Martins, M.F.V., 2007. A velha arte de governar: um estudo sobre politica e elites a partir do Conselho de Estado (1842-1889). Rio de Janeiro: Arquivo Nacional.

Massimo, L. \& Costa, L.D., 2015. Enlarging the Playing Field: Political Circulation of Brazilian Senators in the First Republic. Brazilian Political Science Review, 9(3), pp.116-142. DOI: 10.1590/1981-38212015000300022

Matonyte, I., 2003. The Parliamentary Elite in Post-Communist Lithuania, 1990-2000. Representative Elites in Post-Communist Settings, 8, pp.55-67.

McDonough, P., 1981. Power and Ideology in Brazil. Princeton: Princeton University Press.

Miller, M.C., 1995. The High Priests of American Politics: The Role of Lawyers in American Political Institutions. Knoxville: University of Tennessee Press.

Neiva, P. \& Izumi, M., 2012. Os "doutores" da federação: formação acadêmica dos senadores brasileiros e variáveis associadas. Revista de Sociologia e Política, 20(41), pp.171-192. DOI: 10.5380/rsp.v20i41.31785

Neiva, P. \& Izumi, M., 2014. Perfil profissional e distribuição regional dos senadores brasileiros em dois séculos de história. Revista Brasileira de Ciências Sociais, 29(84), pp.165-188. DOI: 10.1590/s0102-69092014000100011

Nunes, E., 1978. Legislativo, política e recrutamento de elites no Brasil. Dados, 17, pp.53-78.

Pedersen, M.N., 2000. The Incremental Transformation of the Danish Legislative Elite: The Party System as Prime Mover. In . Parliamentary Representatives in Europe 1848-2000. Legislative Recruitment and Careers in Eleven European Countries.

Pestana, M.H. \& Gageiro, J.N., 2008. Análise de dados para ciências sociais: a complementaridade do SPSS. $5^{\mathrm{a}}$ ed. Lisboa: Sílabo.

Rodrigues, L.M., 2014. Pobres e ricos na luta pelo poder: novas elites na política brasileira. Rio de Janeiro: Topbooks.

Samuels, D. \& Abrucio, F.L., 2000. Federalism and Democratic Transitions: The "New" Politics of the Governors in Brazil. Publius, 30(2), p.43. DOI: $10.2307 / 3331087$

Santos, F., 2000. Deputados federais e instituições legislativas no Brasil: 1946-99. In R. Boschi; E. Diniz \& F. Santos, eds. Elites políticas e econômicas no Brasil contemporâneo. São Paulo: Fundação Konder-Adenauer.

Santos, W.G., 1971. Governadores-Políticos, Governadores-Técnicos, Governadores-Militares. Dados, 8, pp.123-128. 
Soares, G.A.D., 1981. A Formação dos Partidos Nacionais. In D.V. Fleischer, ed. Os partidos políticos no Brasil. Brasília: Editora da Universidade de Brasília.

Souza, M.C.C., 1976. Estado e partidos políticos no Brasil (1930-1964). São Paulo: Alfa-Omega.

Vargas, J.M., 2010. Entre a Paróquia e a Corte: uma análise da elite política do Rio Grande do Sul (1868-1889). Santa Maria: Editora da UFSM.

,2012. Um império de cruzes, togas e espadas”. Notas comparativas sobre as elites políticas do Rio Grande do Sul, do Ceará e da Bahia no período monárquico. In F. Heinz, ed. Poder, instituições e elites: 7 ensaios de comparação e história. São Leopoldo: Oikos.

Wessels, B., 1997. Germany. In P. Norris, ed. Passages to Power: Legislative Recruitment in Advanced Democracies. Cambridge, UK: Cambridge University Press.

\section{Outras fontes}

IBGE, 1940. Censo demográfico. Disponível em: http://biblioteca.ibge.gov.br/visualizacao/periodicos/65/ cd_1940_v2_br.pdf. Acesso: em 26 jul. 2016.

TSE, 1952. Dados estatísticos: eleições federais e estaduais, realizadas no Brasil em 1950. Disponível em http://bd.camara.gov.br/bd/handle/bdcamara/ 13043. Acesso em 27.jul.2016. 


\section{Political Regime and Parliamentary Recruitment in Brazil: A Collective Profile of Senators before and after the Dictatorship}

\section{Abstract}

The article rebuilds the collective profiles of the Brazilian Senate benches in three periods: the populist democracy (1945-1964), the military dictatorship (1964-1979) and the regime of transition to liberal democracy (1979-1990). The time frame takes into account three party systems: multipartisan (1945-1965), bipartisan (1965-1979) and multiparty one more time (1979 ahead). The hypothesis we seek to test is the following: changes in the social profile and the profile of the political career of parliamentarians should be related to the type of political regime and, more specifically, with the then current party system. In the case analyzed here, is assumed the attributes of Brazilian Senate members elected under a system of several competing parties must be distinct from attributes of those elected under bipartisanship - even though the electoral rules were the same. In order to analyze the impact of the changes in conditions for access the upper chamber 351 senators were studied. The data shows these representatives had the profile of their careers severely affected by variations in the parameters of political competition imposed by the military dictatorship. The narrowing of opportunity structure, a straight effect of bipartisan system, was responsible for harming competitors without major political experience. With the reintroduction of multiparty politics in the 1982 elections, the characteristics of these parliamentary careers came back to the previous profile previous to 1964 .

KEYWORDS: Federal Senate; parliamentary recruitment; political career; political regime; party system.

This is an Open Access article distributed under the terms of the Creative Commons Attribution Non-Commercial License which permits unrestricted non-commercial use, distribution, and reproduction in any medium provided the original work is properly cited. 


\section{Apêndice}

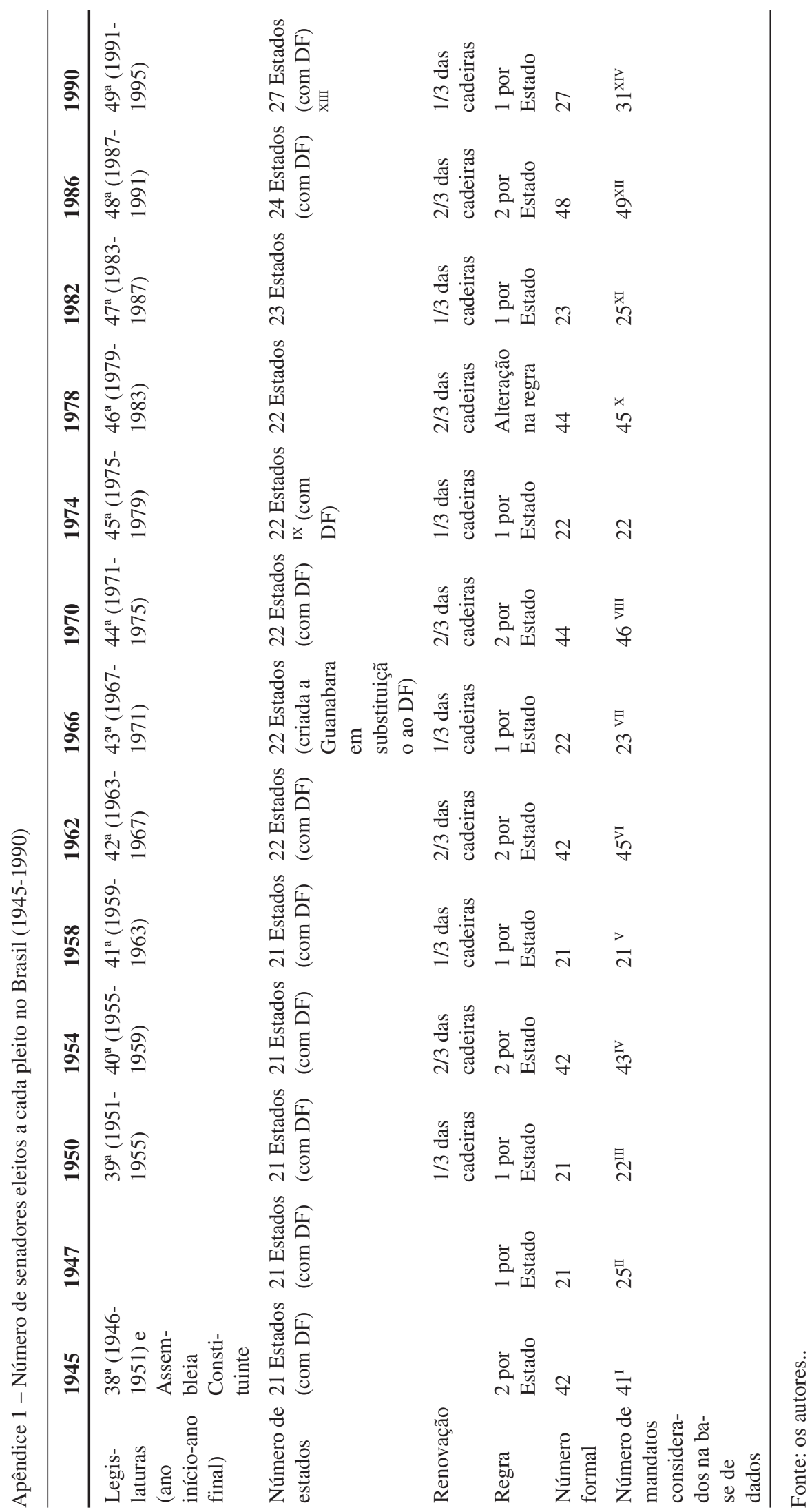




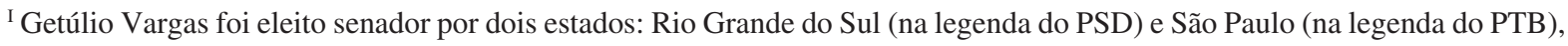
mas assumiu o mandato pelo PSD gaúcho.

${ }^{\text {II }}$ Em 19 jan. 1947 foram eleitos os governadores de estado e o terço restante do Senado Federal. MA, PI, SC e SP elegeram 2 em função de substituições.

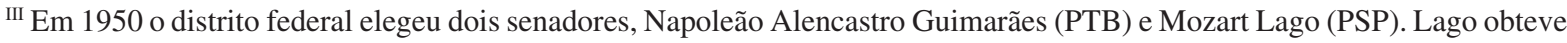
uma votação inferior a Napoleão Alencastro Guimarães - foram 282.874 contra 230.869 votos, de acordo com dados do TSE (1952, p.101). Por esse motivo seu verbete no DHBB informa que ele assumiu um mandato de quatro anos (ao invés de oito), para terminar o mandato de Luis Carlos Prestes, que fora extinto em 7 de janeiro de 1948 (Lei n. 211), por decorrência da cassação do registro do PCB em maio de 1947.

IV Em 1952 o empresário Assis Chateuabriand realizou manobras para obter a vacância de um mandato paraibano, se lançou como candidato único em um pleito suplementar e foi eleito senador pelo PSD. Apesar da derrota nas eleições ordinárias de 1954, a manobra foi repetida e ele retornou ao Senado em junho de 1955, onde permaneceu por mais dois anos. Portanto, em rigor seu mandato não pertence à legislatura de 1950, nem à de 1954, mas como ele saiu do senado em 1957 decidimos posicioná-lo entre os eleitos em 1954. A "manobra" consistiu, segundo seu verbete no DHBB, em obter a renúncia do candidato eleito, Vergniaud Wanderley (que foi nomeado ministro do Tribunal de Contas da União (TCU) em dezembro de 1951), e de seu suplente, Antônio Pereira Diniz. Antônio Diniz era suplente de Vergniaud Wanderley no senado, mas se elegeu deputado federal em outubro de 1950, e segundo seu verbete no DHBB, ele renunciou ao mandato senatorial (para o qual era suplente) e preferiu assumir a cadeira na câmara dos deputados, abrindo a possibilidade do pleito suplementar no qual Assis Chateaubriand foi candidato único.

${ }^{\vee}$ Em 1954 Lucio Bittencourt foi eleito por Minas Gerais para um mandato de oito anos, e faleceu 1955. Devido ao óbito de seu suplente (João Lira Guimarães), foram realizadas novas eleições em 1960, nas quais se elegeu Camilo Nogueira da Gama, que cumpriu os dois anos restantes do mandato de Lucio Bittencourt, e se elegeu para um mandato ordinário em 1962. Para evitar duplicatas, o senador Camilo Nogueira da Gama só aparece na base como titular do mandato em 1962.

${ }^{\text {VI }}$ É criado o estado do Acre que deixa de ser território federal e elege 3 senadores.

${ }^{\text {VII }}$ Em 1966 foram eleitos um senador por estado, exceto no Ceará, que elegeu Paulo Sarasate para um mandato ordinário, e Francisco de Meneses Pimentel para um mandato de quatro anos. Isso se deve ao falecimento do titular, Carlos Jereissati, e seu suplente (Antônio Jorge de Queiroz Jucá), eleitos em 1962. Jereissati faleceu em 1963 e Antônio Jucá em 1965.

VIII Mais duas vagas (Goiás e Guanabara) preenchidas de modo suplementar após a cassação de dois mandatos com a aplicação do AI-5.

${ }^{\text {Ix }}$ Em 1974 Danton Pinheiro Jobim foi eleito senador da Guanabara pelo MDB. Esse estado foi fundido com o Rio de Janeiro em 01 de julho de 1974, mas essa alteração não alterou a quantidade de estados devido à criação do Mato Grosso do Sul, que elegeria novos representantes no pleito de 15 de novembro de 1978.

x A Ementa Constitucional n 08, de 14 de Abril de 1977 (conhecida como "Pacote de Abril") determinou que metade das vagas em disputa no Senado seriam preenchidas por eleição indireta no colégio eleitoral. Assim, nas eleições de 15 de novembro de 1978 as assembleias legislativas de cada estado escolheram 22 indivíduos, e outros 22 senadores foram escolhidos por eleição direta (um para cada estado). A exceção foi o estado do Mato Grosso, que teve direito a três senadores: Gastão Muller (escolhido pelo colégio eleitoral), Benedito Canelas e Vicente Vuolo, ambos eleitos por voto direto. Vicente Vuolo foi eleito para um mandato ordinário, mas Benedito Canelas foi eleito para um mandato de quatro anos. Essa diferença deve-se à criação do estado do Mato Grosso do Sul (pela Lei Complementar nº31, de 11 de Outubro de 1977). Com a criação da nova unidade, o Senador Antônio Mendes Canale (que se elegera pelo Mato Grosso, em 1974) foi transferido para o novo estado, pois seu domicílio eleitoral (a cidade de Miranda) se situava no interior do novo estado. Assim, e devido à criação da nova unidade, o mandato do titular mato-grossense eleito em 1974 foi completado por Benedito Canela - e o estado do Mato Grosso do Sul seria representado no Senado Federal por Antonio Mendes Canale, Pedro Pedrossian e Rachid Saldanha Derzi (esse último eleito pelo colégio eleitoral). O resultado líquido dessas duas alterações foi a eleição de 45 titulares para o Senado Federal em 1978.

${ }^{\mathrm{XI}} \mathrm{O}$ território de Rondônia se transforma em estado e elege 3 senadores.

${ }^{\mathrm{XII}}$ O DF elegeu 1 senador a mais para um mandato de apenas 4 anos a ser renovado em 1990.

${ }^{\mathrm{XIII}}$ Foram criados mais três estados, Amapá, Roraima e Tocantins.

XIV No pleito de 1990 Amapá e Roraima elegeram três senadores. 